invader, scientific workers cannot but be deeply pained by the damage which the enemy is inflicting on the country. "We scientists have reason to feel gratified by the fact that we have been able to help, with our knowledge, to improve the armaments of the army, and to facilitate the struggle against German barbarity."

The audience listened with great interest to the speech delivered by Prof. Maria Petrova, of Leningrad. She remained in Leningrad all through the siege. "It was painful," she said, "to see how German artillery destroyed the scientific and public institutions of the city, but I never for one moment lost faith that the enemy would be defeated. Work was the best answer to the crimes of the barbarians. During the siege I completed twelve scientific investigations."

Igor Grabar told of the appalling destruction by the Germans of monuments of Russian art in Novgorod and in the environs of Leningrad. Prof. P. V. Pavlov, of the University of Odessa, who lived in that city during its occupation by Germans and Rumanians, and Prof. Alyoshin, of the University of Kiev, who likewise saw all the horrors of German occupation, spoke of the damage done by the invaders to scientific and cultural institutions in the Ukraine. This was also the subject of a speech by Alexander Beletsky, of the Ukrainian Academy of Sciences.

Nikolai Nikolsky, member of the White Russian Academy, told the meeting of the 'new order' in German-occupied Minsk. This elderly grey-bearded scholar escaped from Minsk with the aid of White Russian partisans in August 1943. He had spent seven months with a partisan detachment, and only in April 1944 made his way to the "mainland", as partisans call Soviet territory across the front line. Prof. Krisciunas spoke of the plight of the intelligentsia in German-occupied Lithuania. Nikolai Propper-Grashchenkov, corresponding member of the Academy of Sciences, denounced the practices of German physicians. He said that the Soviet medical profession is in possession of irrefutable proofs of the participation of representatives of German science in the killing of prisoners-of-war and of mentally diseased people, and in the bleeding of Soviet children for blood transfusions to such an extent that the children died. They also have documents showing that German surgeons carried out experimental operations on prisoners-of-war.

Alexander Poraj-Koszyc, another member of the Academy, made an inspiring speech in which he called upon the scientifis and professional men of Poland to devote all their efforts to the defeat of Hitlerism.

Many messages of greeting were received from various institutions as well as from private individuals in the Soviet Union and abroad. The meeting enthusiastically adopted the text of a message of greeting to the Commander-in-Chief of the Armed Forces of the U.S.S.R., Joseph Stalin, and issued an appeal to men of science throughout the world. This appeal said, among other things: "Fascism is the most malignant foe of science and culture. ... There is only one way to save human beings and cultural treasures, and that is, to defeat Germany and her satellites at the earliest possible date. ... All of us must take an active part in this struggle. Let every intellectual and every scientific worker who is not fighting 'arms in hand' contribute his mite to the common cause of humanity by intense creative effort."

\section{EARTHQUAKES IN SOUTHERN CALIFORNIA}

RENO GUTENBERG and C. F. Richter have re. cently studied in detail several hundred earth. quakes in southern California with the view of finding out the physical properties of the earth's crust in the region. The first paper under discussion, "Recent Results of Earthquake Study in Southern California", by both authors (Trans. Amer. Geophys. Union, 1943) contains first the travel-time equations of the district. These are :

$$
\begin{array}{ll}
\bar{P}-0=D / 5 \cdot 577 & \bar{S}-0=-0 \cdot 5+(D / 3 \cdot 26) \\
P y=0=1 \cdot 2+(\Delta / 6 \cdot 05) & S y=0=2 \cdot 0+(\Delta / 3 \cdot 64) \\
P n-0=6+(\Delta / 8 \cdot 06) & S n-0=8+(\Delta / 4 \cdot 46)
\end{array}
$$

where $\Delta$ is epicentral distance in $\mathrm{km}$. and $D$ is hypocentral distance for focal depth of $18 \mathrm{~km}$.

The authors state that the terms independent of $\Delta$ in the equations for $P n$ and $S n$ show appreciable variation for shocks in different parts of the region, with maxima of about 9 and 13 respectively in the shocks of northern Owens Valley east of the Sierra Nevadà. This is an effect of the 'root' of the Sierra.

The travel-times indicate no variation in the thickness of the 'granitic' layer, which is about $18 \mathrm{~km}$. Most of the shocks originate near the base of this layer. There is at least one 'intermediate' layer between this and the base of the continental crust (the Mohorovicic discontinuity). The velocity of $P y$ in this layer differs notably from that of the similar wave $P^{*}$ as observed in Europe $(6.05$ instead of $6.4 \mathrm{~km}$. $/ \mathrm{sec}$.). If this is a single layer, its thickness varies from about $20 \mathrm{~km}$. in the coastal area to almost $50 \mathrm{~km}$. in the Sierra region.

The term -0.5 in the equation for $\bar{S}$ represents a frequently noticed discrepancy between the apparent origin-times of $\bar{P}$ and $\bar{S}$. The writers attribute this to development of the fault-fracture with speed greater than the velocity of transverse waves, resulting on the average in early arrival of $\bar{S}$ at the observ-

\begin{tabular}{|c|c|c|c|}
\hline Layer & $\underset{\text { Modulus }}{\text { Bulk- }}$ & Rigidity & $\begin{array}{l}\text { Poisson's } \\
\text { Ratio }\end{array}$ \\
\hline $\begin{array}{l}\text { Granitic } \\
\text { Intermediate } \\
\text { Below Intermediate }\end{array}$ & $\begin{array}{r}4.5 \times 10^{11} \\
5.5 \times 10^{11} \\
12.4 \times 10^{11}\end{array}$ & $\begin{array}{l}2.9 \times 10^{11} \\
3.8 \times 10^{11} \\
6.5 \times 10^{11}\end{array}$ & $\begin{array}{l}0 \cdot 24 \\
0.22 \\
0 \cdot 28\end{array}$ \\
\hline
\end{tabular}
ing stations. The following are mean values of elastic constants (c.G.s. units) from all available data for the region:

J. M. Nordquist is in the course of developing a new application of the magnitude scale in association with these earthquakes. Assuming a special distribution function already employed by E. J. Gumbel in the investigation of flood-statistics ("Statistical Control-Curves for Flood-Discharges." By E. J. Gumbel, Trans. Amer. Geophys. Union, 489-509; 1942) makes it possible to choose a scale for a plot in which the points for various magnitudes fall nearly on a straight line, the level of which is an indication of the degree of activity. This method promises a quantitative definition of seismicity.

The second paper here discussed is "Variations in Physical Properties within the Earth's Crustal Layers", by Beno Gutenberg (Trans. Amer. Geophys. Union, 1943). In it the author states that the traveltimes as well as the amplitudes lead independently to the conclusion that most of the fifty shocks discussed in this second paper originated at the bottom. 
of the Granitic layer. In shocks with faulting completely inside the Granitic layer only, the amplitudes of $P y$ should be about the same as those of $P n$. The fact also that the amplitudes of the various $S$ waves change with distance in a similar way to those of the corresponding $P$ waves indicates that the effect of pressure and temperature on the coefficient of rigidity is relatively the same as on the bulkmodulus.

Gutenberg states that the Mohorovičic discontinuity is at a depth of about $35-40 \mathrm{~km}$. in the coast areas of southern California, but deeper under mountain ranges. The velocity of $P n$ below it is close to $8.0 \mathrm{~km}$. $/ \mathrm{sec}$. At first, the velocities of both $P$ and $S$ increase with depth, probably at a rate similar to that in the upper layers; but the rate of increase falls off rapidly with increasing depth, resulting in a rapid decrease of the amplitudes of $P n$ and $S n$ with distance beyond $\Delta=200 \mathrm{~km}$. Amplitudes of $P n$ and similarly of $S n$ in intermediate shocks without appreciable surface waves, on records of shocks originating at various depths within a radius of about $2,000 \mathrm{~km}$. from Huancayo, Peru, and recorded at the station there, confirm results obtained previously by Gutenberg and Richter concerning the relationship between the epicentral distances at which the amplitudes of $P n$ are very small, and the focal depth of the shocks.

These findings, according to Gutenberg, can be explained on the assumption that at a depth of about $80 \mathrm{~km}$. the melting point of the material is reached. Immediately above that critical depth, the effect of temperature on the bulk-modulus and on the coefficient of rigidity may approach, or even surpass, the effect of pressure. At the critical depth itself, there may be a slight sudden decrease of the wave-velocity. At greater depth, the effect of the temperature on the bulk-modulus and the coefficient of rigidity becomes more and more insignificant. Whereas above the critical depth a certain minimum stress, the strength, is required to start plastic flow, below this depth no appreciable strength exists, and the plastic flow is controlled only by the viscosity of the material.

\section{FORTHCOMING EVENTS}

\section{Saturday, August 19}

assoctation of austrian Engineers, Chemists and Scmentific WORKERS IN GREAT BRITAIN (at Austria House, 260 Oxford Road, Manchester), at 7.30 p.m.-Dr. E. Broda: "Science in Austria (with special reference to the 100 th Birthday of L. Boltzmann)".

\section{Tuesday, August 22}

QUEKETT MICRosoopICAL CruB (at the Royal Society, Burington House, Piccadilly, London, W.1), at 7 p.m.-Exhibition of specimens and discussion.

\section{APPOINTMENTS VACANT}

APPLICATIONS are invited for the following appointments on or before the dates mentioned

SPEECH THFRAPIST (whole-time)-The School Medical Officer, County Hall, Chichester (August 23).

AsSISTANT MASTHR preferably with Graduate or equivalent qualiflcations in Engineering, mainly for work in the Junior Technical School -The Acting Secretary to the Education Committee, 1 Eastbank Street, Southport (August 23).

Street, Southport (August 23).
AssisTANT PSYCHOLOGIST in the School Psychological ServiceThe Director of Education, Education Department, Newarke Street, Leicester (August 25).

GRADUATE TEACHER OF ENGINEFRING (full-time) for Day and Evening Classes in the Crewe Technical College-The Director of Educaing Classes in the Crewe Technical College-The Director of Education, County Edncation Offices, City Road, Chester (August 25). LECTURER IN AGRICUITURAI ZOOLOGY, including ENTOMOLOGY, and
an ASSISTANT ADVISORY OFFICER IN ANIMAL HUSBANDRY - The \&n ASSISTANT ADVISORY OTFICER IN ANIMAL HUSBAN DRY-The Secretary, West of Scot
Glasgow (August 25).
Principal of the Burniay Municipal Colmege-The Director of Education, Education Offices, Burnley (August 26).

Assistant IN BotanY-The Secretary, The University, Aberdeen (August 28).

ADVISER IN AGRICULTURAL ENTOMOLOGY (temporary)-The Regisrar, King's College, Newcastle-upon-Tyne (August 31).

ASSISTANT LEOTURER IN ENGINEERING-The Registrar, The Univer sity, Manchester 13 (August 31).

LECTURER IN GEOGRAPHY - The Secretary, University of Durham, 8 North Bailey, Durham (September 1).

BORODGH ENGINEER AND SURVEYOR to the County Borough of Southampton-The Town Clerk, Town Clerk's Office, Civic Centre, ber 4). Borough ENGINwer AND SURVEYoR-The Town Clerk, Town Hall,
West Ham, London, E.15 (endorsed 'Borough Engineer and Surveyor') West Ham, Lon

LEOTURER IN Physiology-The Secretary, The University, Birm. ingham 3 (September 5).

UNIVERSITY READERSHIP IN PHYsics tenable at King's CollegeThe Academic Registrar, University of London, South Kensington,

CHarn of MINING-The Acting Registrar, The University, Leeds 2 September 30).

LECTURAR IN PHIMOSOPHY - The Very Rev. the Dean, Christ Church, Oxford (October 15)

HYDROGRAPHICAI SURVEYoR for the Basrah Port Directorate, Iraq -The Ministry of Labour and National Service, Appointments De. partment, Sardinia Street, Kingsway, London, W.C.2 (quoting Reference No. O.4962S).

SCIENTIFIC OFFICER (man or woman, temporary) in the Cod Lives Oil (Poultry) Standardisation Laboratory-The Secretary, Natioval nstitute for Research in Dairying, Shinfleld, Reading, Berks.

SPEWCH THERAPIST (full-time)-The Secretary for Education, Education Offices, York.

LECTURER (man or woman, full-time, temporary) IN BIOLOGY in the Leeds College of Technology-The Director of Education, Education Offices, Leeds 1

LFCTURER (WOMan) IN MATHEMATIOS AND BIOLOGY (Nature Study) OR GEOgRAPHY in the Swansea Training College for Women-The Director of Education, The Guildhall, Swansea.

\section{REPORTS and other PUBLICATIONS \\ (not included in the monthly Books Supplement)}

\section{Great Britain and Ireland}

Metallurgical Abstracts (General and Non-Ferrous). Vol. 10, 1943 (New Series). Edited by N. B. Vaughan. Pp. xif +523. (London: Institute of Metals.)
Medical Research Council. War Memorandum No. 3: Economy in the Use of Drugs in War-Time. Revised second edition; with an Appendix on Economy in the Use of Bactericides. Pp. 16. (London H.M. Stationery Office.) $3 d$. net.

Some Recent Advances in Chemistry in relation to Medicine. By Dr. D. H. Hey. Pp. 24. (London : Royal Institute of Chemistry.) [257 National Veterinary Medical Association of Great Britain and Ireland. Publication No. 6: Report on Diseases of Farm Livestock Section 2: Diseases of Sheep. Pp. 101. 108. Publication No. 7 Memorandum on Farm Buildings. Pp. 48. 58. (London: Nationas Veterinary Medical Association.)
[257 Lepidoptera $2:$ Keys for the Identification of the Iepidoptera infesting Store Food Products, by A. S. Corbet and W. H. T. Tams. Pp. 144t plates. (London: H.M. Stationery Office.) 5s. net. [257
[2. British Association for the Advancement of Science. Report of Committee on Post-War University Education. Pp. 52. (London:
British Association.) 28. 6d. Transactions of the Royal Society of Edinburgh. Vol. 61, Part 1 , No, 6: Growth Stages in some Jurassic Ammonites. By Dr Currie. Pp. 171-198+1 plate. (Edinburgh and London : Oliver and Boyd.) 78. 6d.

\section{Other Countries}

League of Nations: Economic, Financial and Transit Department. Food Rationing and Supply, 1943-44. (Publication : 1944 : II.A.3.) Pp. 101. (Geneva: League of Nations ; London: George Allen and Unwin, Itd.) $48.6 d$.

Annals of the New York Academy of Sciences. Vol. 45, Art 7 The Distribution of the Salamanders of the Genus Plethodon in Eastern United States and Canada. By Arnold B. Grobman. Pp. 261-316. (New York: New York Academy of Sciences.) [257 Proceedings of the American Philosophical Society. Vol. 87, No. 5 (May 5, 1944) : Papers on Archæology, Ecology, Ethinology, History, Paleontology, Physics, and Physiology. Pp. ifi +365-460. (Philadelphia : American Philosophical Society.) [257 Commonwealth of Australia : Council for Scientific and Industrial Research. Bulletin No. 178: Food Composition Tables. Compiled by Hedley $R$. Marston and Mary C. Dawbarn. Pp. 104. (Melbourne:
[257 U.S. Office of Education: Federal Security Agency. Leaflet No. 69: Education in China To-day. By C. O. Arndt, Severin K. Turosienski and Tung Yuen Fong. Pp. 12. 5 cents. Vocational Division Leaflet No. 13 : Professional Nurses are Needed. (Revision of Leaflet No. 10.) Pp. vi +30. 10 cents. (Washington, D.C.: Government Printing Office.)
U.S. Department of Agriculture. Technical Bulletin No. 846 : The Cabbage Lonper as a Pest of Lettuce in the Southwest. By K. B. MeKinney. Pp. 30. (Washington, D.C.: Government Printing Office.) 